\section{SEM Switzerland: making sport safer and breaking down silos}

\author{
Boris Gojanovic (D) 1,2
}

The past year has been a repetitive tale of challenges and adaptations, as each new wave of the pandemic spread across the world. One striking feature has been each country or region's race for 'safe ground', including border closures and idiosyncratic rules and regulations. When the going gets tough, everyone seems to revert to strategies of the past, usually involving silos and fences. Sometimes, this happens in medicine too. As problems become more complex, specialised care and specialists become more isolated from one another, meaning they cannot see the forest for the trees.

\section{INTERDISCIPLINARITY: THE HEART OF SPORTS AND EXERCISE MEDICINE (SEM)}

SEM clinicians have a strong culture of transversal collaboration, necessary because of the complex multistakeholder environment and the extreme pressure we have to navigate. As challenging as it is, the pandemic has added a new layer by erasing most in-person meetings. Of course, we have all adapted and found new ways to interact, teach or learn. Education has been a challenge but also left space for innovation and prototyping. We quickly realised that well-conducted 'Zoom' calls can boost productivity and efficiency in project advancement. We have been able to integrate people from different horizons (and countries) faster than ever. The next challenge will be to revert to more human interaction while harnessing the potential of 'meeting' technology.

\section{CRISIS IN A CRISIS}

Another crisis requiring critical and multilevel action is the harassment and abuse faced by some Swiss athletes. We

${ }^{1}$ Hôpital de La Tour, Swiss Olympic Medical Center, Geneva, Switzerland

${ }^{2}$ Interdisciplinary Center for Adolescent Sports

Medicine, Woman-Mother-Child Department (DFME), Lausanne University and CHUV Hospital, Lausanne, Switzerland

Correspondence to Dr Boris Gojanovic, Hôpital de La Tour, Swiss Olympic Medical Center, 1217 Meyrin, Geneva, Switzerland; boris.gojanovic@latour.ch have been able to set up a working group to support the ongoing investigations and projects in safeguarding for athletes. The Health4Sport group unites the four health-oriented partner societies in Swiss sports: SEM Switzerland (SEMS, www. sems.ch), Swiss Sports Physiotherapy Association (www.sportfisio.ch), Swiss Sports Nutrition Society (SSNS, www. ssns.ch) and Swiss Association of Sport Psychology (www.sportpsychologie.ch). Together we present in this issue the 13 key principles to consider in safeguarding that have emerged from our collaboration (see page 952).

\section{SEMS ANNUAL CONGRESS:}

\section{MAGGLINGEN, 21-22 OCTOBER 2021}

This year, we will welcome our national SEM community to Magglingen, home of the Federal Office for Sport (FOSPO) and its training facilities. We will continue our interdisciplinary knowledge sharing with symposia on sports nutrition led by SSNS and on sports science with the participation of FOSPO's team along with international speakers. In addition to multiple workshops bringing applicable knowledge to the participants and symposia on overuse injuries, we will be hosting a roundtable on harassment and abuse with key clinical and institutional stakeholders, highlighting this critical area and initiating our educational drive. As always, our congress is multilingual, so we encourage you to come and experience the Swiss way of communicating.

\section{IN THIS SWISS SPORTS MEDICINE ISSUE}

As always, we are honoured to present a great mix of papers, some of which echo our current challenges to bring more health focus in sports and society. Nabhan et al discuss the importance of health information systems to monitor athletes (see page 945) and report on the periodic health evaluation practices of top-performing nation at the Olympics (see page 961). Dr Tim Gabbett's group discuss tissue-specific load monitoring (see page 947) and its potential use to manage injuries better, while Dr Jane Thornton and her British Journal of Sports Medicine (BJSM) editorial colleagues remind us that sports and physical activity are essential aspects of a healthier world and that SEM clinicians can contribute to expand their spectrum of practice towards that of public health (see page 949). Our country had the privilege to host the 2020 Youth Olympic Games in Lausanne in February, just before the pandemic hit Europe, and in this issue Palmer et al report on injuries and illnesses during the event (see page 968).

We are sure you will enjoy this issue, and we thank the BJSM editorial team for creating an environment that connects the world of SEM.

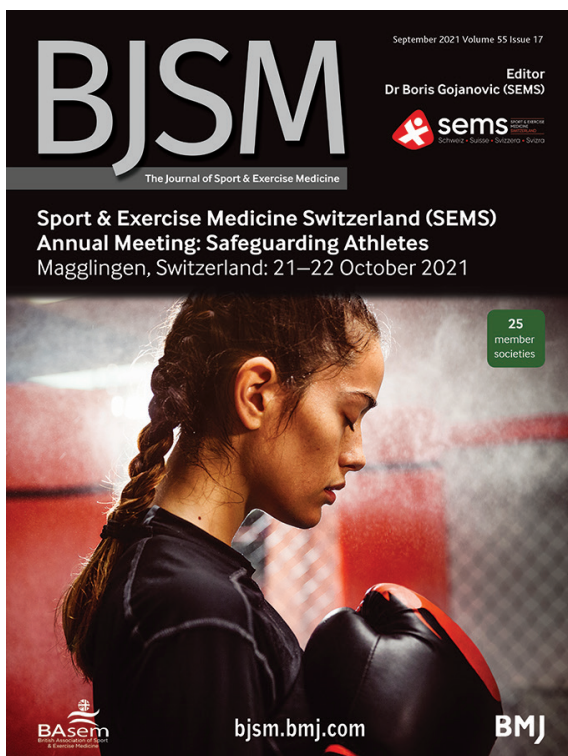

Twitter Boris Gojanovic @drsportsante

Contributors BG is the sole author of this paper.

Funding The authors have not declared a specific grant for this research from any funding agency in the public, commercial or not-for-profit sectors.

Competing interests None declared.

Patient consent for publication Not required.

Provenance and peer review Commissioned; internally peer reviewed.

(c) Author(s) (or their employer(s)) 2021. No commercial re-use. See rights and permissions. Published by BMJ.

A) Check for updates

To cite Gojanovic B. Br J Sports Med 2021;55:943.

Accepted 16 July 2021

Br J Sports Med 2021;55:943

doi:10.1136/bjsports-2021-104594

\section{ORCID iD}

Boris Gojanovic http://orcid.org/0000-0001-50759371 